\title{
Article \\ Assessment of Collaboration-Based and Non-Collaboration-Based Logistics Risks with Plithogenic SWARA Method
}

\author{
Alptekin Ulutaş ${ }^{1}$, Ieva Meidute-Kavaliauskiene ${ }^{2, *}{ }^{\mathbb{C}}$, Ayse Topal $^{3}$ and Ezgi Demir ${ }^{4}$ \\ 1 International Trade and Logistics Department, Sivas Cumhuriyet University, Sivas 58140, Turkey; \\ aulutas@cumhuriyet.edu.tr \\ 2 Business Management Faculty, Vilnius Gediminas Technical University, Saulètekio al. 11, \\ LT-10223 Vilnius, Lithuania \\ 3 Business Department, Niğde Ömer Halisdemir University, Nigde 51240, Turkey; ayse.topal.ohu@gmail.com \\ 4 Management Information System Department, Faculty of Management, Gebze Technical University, \\ Gebze 41400, Turkey; ezgidemir@gtu.edu.tr \\ * Correspondence: ieva.meidute-kavaliauskiene@vilniustech.lt
}

Citation: Ulutaş, A.;

Meidute-Kavaliauskiene, I.; Topal, A.;

Demir, E. Assessment of

Collaboration-Based and

Non-Collaboration-Based Logistics Risks with Plithogenic SWARA

Method. Logistics 2021, 5, 82.

https: / / doi.org/10.3390/logistics

5040082

Academic Editor: Robert Handfield

Received: 22 September 2021

Accepted: 12 November 2021

Published: 22 November 2021

Publisher's Note: MDPI stays neutral with regard to jurisdictional claims in published maps and institutional affiliations.

Copyright: (c) 2021 by the authors. Licensee MDPI, Basel, Switzerland. This article is an open access article distributed under the terms and conditions of the Creative Commons Attribution (CC BY) license (https:// creativecommons.org/licenses/by/ $4.0 /)$.

\begin{abstract}
Background: Uncertainty is the major source of hazards, and it is present in a wide range of business activities. Due to the high level of unpredictability in logistics operations, the logistics sector has traditionally operated in a high-risk environment. These risks have become considerably more complicated as the corporate environment has changed in recent years, such through globalization, environmental concerns, and changes in demand. As a result, in order for a logistics firm to thrive, it is necessary to evaluate and assess the risks associated with logistics. Methods: The Plithogenic Stepwise Weight Assessment Ratio Analysis (SWARA) has been used in this study to assess the logistics risks. The logistics risk considered in this study are transportation-related risks, purchasing-related risks, inventory-related risks, information-related risks, packaging-related risks, operational-related risks, geographical location-related risks, natural disaster-related risks, and organization-related risks. Results: The most significant logistics risks are found to be Inventory-Related Risks, while the least significant are Geographical Location-Related Risks. When compared to the standard SWARA approach, the Plithogenic SWARA method may be employed in group decision-making issues without losing information. Conclusions: The proposed technique will help logistics professionals make informed decisions and manage and analyze risks more efficiently. This study will also contribute to the literature as it is the first time that logistical risks have been addressed by utilizing the Plithogenic SWARA technique.
\end{abstract}

Keywords: logistics risks; MCDM; plithogenic SWARA

\section{Introduction}

Uncertainty is the main source of the risks, and it is involved in many business operations. Companies are getting more concerned about risk and risk management processes as the markets getting more dynamic and unpredictable due to several factors such as demand, financial issues, and environmental factors. Besides, the company often faces risks in its own departments, such as the marketing department, operations department, human resources department, and finance department, etc. Therefore, risk has been widely researched in the literature and different definitions appeared for risk term as risk encompasses a wide range of concepts and can be classified according to a variety of factors. Risk refers to the likelihood of unfavorable outcomes from a certain event [1]. The International Organization for Standardization ISO Norm 31000 provides the widest definition of risk as the impact of uncertainty on objectives [2]. It is usually expressed in terms of risk sources, which are elements having the potential to cause risk, potential events which are incidences or changes in a specific set of conditions, their consequences, which are the consequence 
of an occurrence that has an impact on objectives, and their probabilities, which are the chances of something occurring [2,3].

Business risk, according to Deloach [4], is the amount of uncertainty that the organization must comprehend and successfully manage while it executes its plans to achieve its business goals and produce or generate value. From a quantitative perspective, risk has been defined as a characteristic that represents the set of possible outcomes, as well as the range of relative probability for each outcome [5].

Risk management procedure, which has three important steps; identification, categorization, and assessment, has been designed to mitigate risks [6]. Identification entails evaluating all potential risks in a given situation. Risks are classified into homogenous categories for risk assessment and risk reduction techniques in categorization. Managers determine how to respond to categorised risks during risk assessment. Several researches on risk assessment and management in various sectors can be found in the literature. Radanliev et al. [7] conducted risk assessment for the internet of things (IoT) in the cyber market. Birkel et al. [8] explored the potential risks in Industry 4.0 and presented a framework for the risks that may occur during Industry 4.0 adoption. Lyu et al. [9] assessed risks in construction with fuzzy Analytic Hierarchy Process (AHP).

The logistics sector has always operated in a high-risk environment due to uncertainty in logistics operations since the beginning, such as robbery, weather conditions and environmental factors. Humanitarian logistics has especially involved high risks due to the uncertain environmental conditions brought by unexpected disasters. Disasters either natural (earthquakes, floods) or man-made (terrorist attracts) have devastating effects on people and states; therefore, humanitarian logistics to deal with the consequences of these effects is a significant operation. Van Wassenhove [10] stated that humanitarian logistics are constantly confronted with unknown conditions, unlike in private sector logistics.

Hapeman [11] categorized humanitarian logistics risks into 5 groups: economic, social, environmental, infrastructural, and political. However, with changing conditions in the business environment in recent years such as globalization, environmental issues and changes in demand, risks in private sector logistics have evolved to be much more complex. Now, it is critical to examine and assess the risks related to logistics for a logistics company to succeed. The risks in logistics have been summarized by Oklander and Yashkin [12] as the possibility of business risk such as a cut in supply flow and loss in production, property damage due to natural disasters such as earthquakes and floods, robbery, legal risks, and technological risks. Baharmand et al. [13] identified risks in "incountry transportation" of humanitarian aid supply chains. Chand et al. [14] explored the risks and uncertainties in a supply chain of Indian companies by using Analytic Network Process (ANP) and Multi-Objective Optimization on the basis of Ratio Analysis (MOORA) methods. Kubasova et al. [15] discussed logistics risk in construction projects. Khan et al. [16] identified the risk factors related to halal food supply chains and prioritized them with fuzzy AHP. Panjehfouladgaran and Lim [17] identified risk variables and their clusters in reverse logistics. The risks and uncertainties related to logistics are examined and the most significant logistics risk is identified in this study by using plithogenic Stepwise Weight Assessment Ratio Analysis (SWARA) method. The proposed method will assist in making accurate judgments and efficiently managing and analyzing group decision-making problems without losing information. In the traditional SWARA method, individual judgments of decision-makers cannot be fully addressed in group decisionmaking problems, so information loss occurs. The proposed method prevents this loss of information by means of the plithogenic aggregated operators. This study will contribute to the literature by developing a new MCDM method called Plithogenic SWARA. Since the multi-criteria decision-making methodology has been studied, the literature review has been examined in two parts: logistics risk and multi-criteria decision-making studies in logistics risks.

This study consists of six sections. In the next section, literature about the risks and MCDM methods to deal with the risks has been reviewed. In the third section, Plithogenic 
SWARA method has been explained. In the fourth section, Plithogenic SWARA method has been applied for assessment of logistics risks. In the fifth section, results are discussed, while in the sixth section, a conclusion is made.

\section{Literature Review}

Within the scope of risk studies, Cavinato [18] gathered risks in international supply chain and network structure. These risks were classified as physical, financial, informational, relational, and innovational, respectively. Kubasova et al. [15] considered risk management as the sustainability of businesses. In this context, they examined logistics risks as a source of structural support. Construction projects have been considered as a case study and operational logistics activities have been discussed. Jereb et al. [19] discussed logistics process risks in the supply chain and determined that the lack of standardization and model are important factors in the supply chain risk. Pokrovskaya et al. [20] devoted the logistics risks for optimizing company's transportation process, aiming to reduce uncertainty in the organizations. Prakash et al. [21] handled a multi-echelon closed-loop supply chain model in the supplier's quality risks and logistics risks. These risks have been modelled by using mixed integer linear programming. Cagliano et al. [22] studied risks in a special logistics area: blood transfusion. Wang and Regan [23] handled third party logistics (3PL) risks and discussed the measures of risk prevention. They discussed the risk reduction measures for logistics outsourcing to structure distribution networks and gained competitive advantages. Wang et al. [24] studied supply chain risks for logistic innovation in the Australian courier firms.

Ofluoglu et al. [25] identified and analyzed disaster logistics risks in the literature from January 2011 to December 2018. It was found that demand risk is the most considered disaster logistics risk and the facility location problem is the most indicated disaster logistics issue. Also, it was identified that stochastic programming is the most used methodology under risk conditions. Kodym et al. [26] proposed a risk framework in the concept of Logistics 4.0. It has classified risk as economic risks, technical and IT risks, social risks, ecological risks, and legal/political risks. Selviaridis et al. [27] conducted a survey in the concept of buyers and suppliers of logistics services in UK. They classified risks as strategic, financial and operational risks. Li-jun [28] discussed different risks in logistics outsourcing as contract risks, management risks, information risks, market risks, and financial risks, respectively. Salanta and Popa [29] handled main outsourcing logistics risks for avoiding failure and termination of agreements for Romanian practitioners and academics. These risks are loss of control, informational risks, vendor opportunism, deterioration of service, poor communication, poor provider competence, lack of shared goals, loss of power, poor strategic development, and internal governance risks, respectively. Liu et al. [30] investigated the risks for dangerous goods in marine logistics. They provided preventative measures to avoid accidents in marine logistics for dangerous goods to increase sustainability and security. Babazadeh and Razmi [31] used robust stochastic programming for overcoming operational and disruption risks in the agile supply chain. It has been shown that the robust model is efficient in terms of cost. Moslemi et al. [32] analyzed risk factors in container shipping and logistics services using a dual perspective. Varzandeh et al. [33] handled global supply chain management risks associated with global economy. The risks in this study have been categorized for small, medium and large organizations. Wu and Chaipiyaphan [34] conducted delivery vulnerability in logistics risk management. They investigated accumulated data to utilize pragmatic business analytics insights on logistic management. Pfohl et al. [35] proposed a structural analysis for supply chain risks in two German trade companies. Yongsheng and Li [36] handled logistics risks of enterprises by using balanced scorecard (BSC) in order to increase the performance of companies. Jia and Zhang [37] studied risks in maritime logistics services because of higher uncertainty. In this study, an early warning model has been built for decreasing maritime logistics service risks by stimulating other risks. Liu \& Wang [38] handled cold chain logistics risks for fresh food in the circulation process. For this purpose, a game 
model was established for operating risks. Then, the impact of different parameters was analyzed. Chang et al. [39] conducted the risks in container shipping operations. Risks have been classified as information, physical, and payment risks. Roşca et al. [40] discussed risks in a port logistics system. The significant risks in port logistics have been investigated. Chen et al. [41] handled emergency logistics in the rescue process after sudden disasters. In this study, reliability factors of materials have been introduced. Then, emergency logistics system was identified. The improved epidemic model to analyze the influencing factors of risk propagation mechanism was developed. Yan and Suo [42] classified logistics risks in financial businesses. A Bayesian network has been constructed to identify the risk levels. Lai et al. [43] discussed port risks in maritime transportation networks. A conceptual discussion of port logistics risks was conducted and define-measure-analyse-improvecontrol (DMAIC) implementation framework for potential risk management operations was used. Gao [44] discussed the features and development of the logistics of fresh goods in e-commerce, and the risks involved. Lee [45] proposed arctic shipping logistics risks in the concept of fourth industrial technology. Lakehal \& Tachi [46] discussed several constraints, such as delays, flexibility, diversity of merchandise, and road risks in road transportation. Wang [47] studied impacts of the supply chain risks of the transportation sector in Australia. In this study, risks have been classified from company, customer, and environmental perspectives.

Behl and Dutta [48] studied supply chain management focused on humanitarian logistics for the purpose of drawing a roadmap a performance evaluation. Sahin et al. [49] proposed a mathematical model to define the location and quantity of containers, as well as the type and amount of relief supplies to store. Also, it has been tested using earthquake risk data, estimates of population under risk, and the distances between cities. Baporikar and Liina [50] studied global and sudden disasters such as earthquakes, tsunamis, hurricanes, and epidemics to evaluate the challenges faced by humanitarian logistics in Namibia. Beresford and Pettit [51] proposed a Humanitarian Aid Logistics research for identifying, assessing, and resolving key problems in humanitarian aid logistics and supply chain relationships to the reduction of the human cost of disasters. Oloruntoba et al. [52] suggested new theory driven research themes and outlines potential directions for future of operations management in humanitarian contexts.

Cozzolino [53] underlined the critical role of logistics and supply chain management in the humanitarian logistics concept for the disaster management. Oloruntoba and Gray [54] identified "agility" in supply chain management for humanitarian aid by developing a model. Kosacka-Olejnik [55] studied academic signs of progress in logistics maturity of the service industry. Oleśków-Szłapka and Stachowiak [56] discussed the framework of Logistics 4.0 maturity model to develop a road map for businesses' pilot research. Facchini et al. [57] proposed a model to optimize the production process and organization structures in Industry 4.0 vision. In this study it has been defined to overcome the growing uncertainty and dissatisfaction in implementing Industry 4.0 vision. The model highlighted the pros and cons of two investigated companies regarding the transition towards Logistics 4.0 technologies.

When the literature review was examined from multi-criteria decision-making viewpoints, the following studies were found.

Chand et al. [14] conducted risk management in supply chain by using ANP based MOORA methodologies. Khan et al. [16] handled halal food supply chain risk by using fuzzy AHP. Duran and Zafeirakopoulos [58] discussed reverse logistics risks by using ANP based Complex Proportional Assessment (COPRAS) methodologies. Mzougui et al. [59] handled supply chain risks with the framework of Failure Mode, Effects and Criticality Analysis (FMECA), AHP, and fuzzy Decision-Making Trial and Evaluation Laboratory (DEMATEL) methods. Teniwut [60] conducted an integrated multi-criteria decision-making (MCDM) with fuzzy AHP to provide a better decision in the problems involving various related complicated factors. Vishwakarma et al. [61] developed a model to sustain global health of human beings and businesses. For this purpose, fuzzy AHP was used 
to prioritize and sort risks in the pharmaceutical supply chain. Senthil et al. [62] ranked risks with AHP based fuzzy Technique for Order Preference by Similarity to Ideal Solution (TOPSIS) methodology in reverse logistics. Ulutaş et al. [63] developed a new method called Plithogenic PIvot Pairwise RElative Criteria Importance Assessment (PIPRECIA) to prioritize logistics risks.

Govindan and Chaudhuri [64] analyzed the relationships among risks in 3PLs by using DEMATEL method. Karakurt et al. [65] proposed a new risk analysis method for the logistic sector with fuzzy Best Worst Method (FBWM). Yousefi et al. [66] ranked logistics processes risks with a sequential multi-stage fuzzy cognitive map (SMFCM) and process failure mode and effects analysis (PFMEA). They discussed all logistics sub-processes to make a risk prioritization. Thakkar [67] used DEMATEL-ANP (DANP) to measure the overall supply chain risk. Gaudenzi and Borghesi [68] evaluated supply chain risks with AHP. Shanker et al. [69] handled 3PL supply chain risks in a restaurant with fuzzy AHP and fuzzy TOPSIS methods. Cheng and Yu [70] studied risks in emergency logistics regarding natural disasters with fuzzy logic and Delphi method. Kwak et al. [71] discussed international supply chains by means of failures in international logistics processes. For this purpose, international logistics risks have been proposed in a holistic approach based on Delphi method.

Integration and collaboration have become popular during the 1980s and 1990s in supply chain management [72]. Logistics management is a part of supply chain management; thus, these two terms also became applicable in logistics management. Integration and collaboration are critical for maintaining a strong relationship and improving performances [73]. Integration is needed among the companies working together in the same network or chain in order to know what is delivered to the end consumer in terms of cost and service [72]. Collaboration among companies develops long-term relationships based on personal trust, resulting in benefits such as collaborative knowledge generation, sharing expertise, and understanding the partner's goals, as well as lower logistical costs and the production of value for supply chain [74,75]. Trust is regarded as a binder among collaborating companies [76]. It can be defined as the readiness to become subject to someone whose actions are beyond his control [77]. Communication is another element that is needed for effective collaboration. It is the glue that holds companies in a supply chain together in a bilateral way with a balanced multilevel interaction [78].

Unlike the studies related to logistics, risks were studied via the concept of humanitarian logistics and maturity models. Also, in MCDM methodologies the criteria of logistics risks have been discussed in the literature. However, in this study, two main groups of risks will be examined: collaboration-based risks and non-collaboration-based risks. In addition, these risks are valid throughout all of the logistics industry. The proposed methodology is discussed for the first time in this study.

\section{Materials and Methods}

In comparison to other multi criteria decision making methods for determining criteria weights based on human knowledge, the SWARA method appears to be simple and adaptable [79]. The neutrosophic set, in combination with the contradiction degree, are used with SWARA method in this study to determine the experts' collective judgment effectively. The Plithogenic SWARA method is developed to assess the logistics risks and to identify the most significant logistics risk in this study.

\subsection{Neutrosophic Set}

The neutrosophic theory is used effectively in the presence of inconsistency in the data. It provides a three-way decision with the neutrosophic set to make successful decisions [80]. Three neutrosophic membership functions are presented to aid in the computation of weights related to alternatives and criteria for selecting the best option. $\widetilde{b}=\left\langle\left(b_{1}, b_{2}, b_{3}\right) ; \alpha, \theta, \beta\right\rangle$ can be determined as a single-valued triangular neutrosophic set 
consisting of falsity membership function $S_{b}(x)$, indeterminate membership $I_{b}(x)$, and truth membership $K_{b}(x)$ as follows [81]:

$$
\begin{gathered}
K_{b}(x)=\left\{\begin{array}{cc}
\alpha_{b}\left(\frac{x-b_{1}}{b_{2}-b_{1}}\right) & \text { if } b_{1} \leq x \leq b_{2} \\
\alpha_{b} & \text { if } x=b_{2} \\
0 & \text { otherwise }
\end{array}\right. \\
I_{b}(x)=\left\{\begin{array}{cc}
\left(\frac{b_{2}-x+\theta_{b}\left(x-b_{1}\right)}{\left(b_{2}-b_{1}\right)}\right) & \text { if } b_{1} \leq x \leq b_{2} \\
\theta_{b} & \text { if } x=b_{2} \\
\left(\frac{x-b_{2}+\theta_{b}\left(b_{3}-x\right)}{\left(b_{3}-b_{2}\right)}\right) & \text { otherwise }
\end{array}\right. \\
S_{b}(x)=\left\{\begin{array}{cc}
\left(\frac{b_{2}-x+\beta_{b}\left(x-b_{1}\right)}{\left(b_{2}-b_{1}\right)}\right) & \text { if } b_{1} \leq x \leq b_{2} \\
\beta_{b} & \text { if } x=b_{2} \\
\left(\frac{x-b_{2}+\beta_{b}\left(b_{3}-x\right)}{\left(b_{3}-b_{2}\right)}\right) & \text { if } b_{2} \leq x \leq b_{3} \\
1 & \text { otherwise }
\end{array}\right.
\end{gathered}
$$

\subsection{Plithogenic SWARA}

The beginning, creation, development, and evolution of new entities from the synthesis of contradictory (dissimilar) or non-contradictory numerous old entities are referred to as plithogeny [82]. A plithogenic set is defined as a set enclosing several elements described by a number of properties, and each property has values [81]. In this study, plithogenic aggregation operators, which are a part of the plithogenic set, will be used to enhance SWARA method in terms of decreasing information loss. When compared to the traditional SWARA method, the Plithogenic SWARA method may be used in collaborative decision-making situations without sacrificing information. The proposed method will assist logistics professionals in making better informed decisions and managing and analyzing risks. The Plithogenic SWARA method's steps are represented below.

Step 1: Factors are identified by decision-makers (DMs). DMs sequenced these factors from the most significant to the least significant.

Step 2: Beginning with the second factor, the $j$ th factor and the $j-1$ th factor are compared.

Step 3: A contradiction degree acquires better accuracy for plithogenic aggregation operations [83]; therefore, the contradiction degree is identified between each criterion and the dominant criterion value [82]. Thus, the contradiction degree $(c: V \times V \rightarrow[0,1])$ is determined.

Step 4: The opinions of all decision-makers are integrated with Equation (4).

$$
\begin{aligned}
& \left(\left(b_{i 1}, b_{i 2}, b_{i 3}\right), 1 \leq i \leq n\right) \wedge p\left(\left(t_{i 1}, t_{i 2}, t_{i 3}\right), 1 \leq i \leq n\right) \\
& \quad=\left(b_{i 1} \wedge_{F} t_{i 1}, \frac{1}{2}\left(b_{i 2} \wedge_{F} t_{i 2}\right)+\frac{1}{2}\left(b_{i 2} \vee_{F} t_{i 2}\right), b_{i 3} \vee_{F} t_{i 3}\right), 1 \leq i \leq n
\end{aligned}
$$

where $\vee_{F}$ and $\wedge_{F}$ indicate the fuzzy t-conorm and t-norm, respectively.

Step 5: The crisp values $\left(v_{j}\right)$ are obtained from the conversion of the neutrosophic values $\left(\widetilde{v}_{j}=\left\langle\left(v_{1 \mathrm{j}}, v_{2 \mathrm{j}}, v_{3 \mathrm{j}}\right) ; \alpha_{j}, \theta_{j}, \beta_{j}\right\rangle\right)$ as follows [63]:

$$
U\left(v_{j}\right)=\frac{1}{9}\left(v_{1 \mathrm{j}}+v_{2 \mathrm{j}}+v_{3 \mathrm{j}}\right) \times\left(2+\alpha_{j}-\theta_{j}-\beta_{j}\right)
$$

Step 6: The last ranking of the factors is acquired by uniting the rankings of the factors of the DMs with the arithmetic mean. After this, the process is continued with steps of the traditional SWARA [84].

Step 7: $y_{j}$ coefficient is calculated as:

$$
y_{j}=\left\{\begin{array}{cc}
1 & j=1 \\
1+v_{j} & j>1
\end{array}\right.
$$


Step 8: $z_{j}$ recalculated weight is acquired as:

$$
z_{j}=\left\{\begin{array}{cc}
1 & j=1 \\
\frac{z_{j-1}}{y_{j}} & j>1
\end{array}\right.
$$

Step 9: The final weights $\left(w_{j}\right)$ of criteria are obtained as follows:

$$
w_{j}=\frac{z_{j}}{\sum_{k=1}^{n} z_{k}}
$$

\section{Application}

Logistics risks are assessed with the Plithogenic SWARA method in this study. Data were obtained from five experts working in the field of logistics for the evaluation of these risks. Especially during COVID-19, logistics risks have become a crucial part of supply chain. In order to overcome the problem of logistics risks, the project has been studied in this paper. In this light, a consultancy service was received for logistics risk management. In this consultancy, experts have been proposed according to their expertise in the different parts of logistics and sectors they are working on. The study was carried out for 8 weeks. Firstly, the consultancy firm suggested 20 experts who have been working in the logistics sector for many years. Emails were sent to each of these experts. Only 5 of these experts responded to e-mails. Therefore, in this study there are five experts. Expert 1 is a general manager who has 20 years experience in the field of logistics. Expert 2 is a consultant. Additionally, he has a PhD, and has 22 years of experience in the field of logistics. Expert 3 is an associate professor, and he has been working in the logistics sector for 12 years. Expert 4 is an industrial engineer, and she has been working in the logistics area for nearly 15 years. She is a department member in a logistics company. Expert 5 is also a consultant. She has been working at least 10 years in the field of risk assessment. In this study criteria have been determined by literature review. Later, the methodology was developed by an associate professor academician. In addition, the other people in the consultancy company discussed in the meetings. In the 8-week meetings, the criteria in the literature were discussed, and new criteria were added and removed. While determining the criteria, the risk criteria have been divided by the parts by means of a risk expert consultant. In addition, the criteria were developed by examining the distance functions in detail.

The logistics risks to be used in the assessment were determined by these experts. Nine logistics risks were determined by experts and were classified into two main groups, which are collaboration-based and non-collaboration-based logistics risks. Collaboration-based risks can be defined as the risks faced in the logistics activities carried out in collaboration. In other words, it can be defined as the risks that arise in performing logistics activities with outsourcing companies (third-party logistics provider, fourth-party logistics provider and fifth-party logistics provider, etc.). Non-collaboration-based risks can be defined as risks that are independent of any collaboration. Collaboration-based logistics risks in this study are transportation-related risks, purchasing-related risks, inventory-related risks, information-related risks, packaging-related risks and operational-related risks. On the other hand, non-collaboration-based risks are geographical location-related risks, natural disaster-related risks, and organization-related risks. Detailed descriptions of these nine logistics risks are presented below. The risks explained above have been selected in this study because they cover most of the risks faced in logistics sector as suggested by the experts interviewed.

Geographical Location-Related Risks (GLR): With the globalization, logistics operations spread to the outside of the certain locations. A business that is offering logistics in a specific location began to give service in regional and international markets. Although expanding location increased the profit, it brought risks such as challenges in transporting products to or from a certain location due to the differences in landscapes, climate and cultures. The risks caused by geographical difficulties according to transportation modes 
used are called GLR. These geographic challenges can be as follows: the difficulty of transportation by road and/or rail due to landforms, the presence of a climate that adversely affects transportation by air, or being in a region far from the airport, and being in a region far from the railways, etc.

Transportation-Related Risks (TPR): Transportation is the main operation in logistics. Goods are moved from seller to buyer with transportation and logistics' main objective is to handle transportation effectively. Therefore, transportation risk is important. Transportation risks encompass concerns such as driver mistakes, missing and improper procedures involving products exposed to trade in packing and loading processes. These risks include as follows: delays in logistics activities due to transportation, incomplete delivery of goods/products, damage to goods in transportation, loading and unloading processes, etc.

Natural Disaster-Related Risks (NDR): These risks originate from the nature; therefore, they are difficult to prospect before. The examples to natural disasters can be given as storms, floods, and earthquakes which can render equipment and safety of transportation systems useless. The following examples can be given for these risks: damage to the logistics warehouse in flood/earthquake, landslides preventing road transport, and storms preventing air transport, etc.

Purchasing-Related Risks (PCR): Purchasing risks refers to the possibility of a failing in the procurement process. Failures in the purchasing process can result in financial losses and delays. This involves purchasing consumables, capital investments, estate, equipment, services (consultancies, professional services, building management), and outsourcing.

Inventory-Related Risks (IVR): Clients expect from logistics businesses to deliver the goods in a timely fashion and satisfactorily. Businesses must reduce inventory risks to guarantee that these expectations are regularly met to satisfy clients. Inventory risk refers to the probability that the quality or worth of the business's products would deteriorate in the storage. Incorrect forecasting, incorrect supplier selection and theft can be given as an example to inventory risks. In addition, the deterioration of goods, the expiration of the goods, the emergence of excess inventory costs, etc., are caused by incorrect inventory management.

Information-Related Risks (INFR): Every business has information that is important to its success such as information about customers and production management, product ideas, marketing strategy, and so on. The likelihood that the information provided by a business is incorrect or deceptive is known as information risk and it affects the whole operation of a business. Information-Related Risks that are very common in logistics, in general, are as follows: wrong goods shipped, wrong quantity order delivered, wrong delivery date, etc.

Organization-Related Risks (ORR): It can be defined as the logistics risks associated with the organization. Organizations operate in a very volatile environment. Regulators, rivals, consumers, and social expectations are just a few of the external factors that a company faces. An example of organizational risk can be given as threats to stakeholders, including failing to comply with regulatory requirements or damage to a company's reputation or brand.

Packaging-Related Risks (PKR): Packaging is important in logistics to avoid breakings, spoiling and hygiene of the goods transported. Packages may be subjected to a variety of accidents such as falling during handling. Any product can be compressed at some point during its storage or transit. The integrity of the goods in the packaging is affected by vibrations, which can lead to breakage or degradation. The durability of packages may be affected by temperature and humidity. Examples of these risks are as follows: damage or deterioration of the product due to incorrect packaging, easy damage to the packaging, and reduced carrying capacity due to the large packaging, etc.

Operational-Related Risks (OPR): An incident that has a negative impact on the functioning of an operation after it has been commissioned is referred to as operational risk. These risks are mostly under the company's control. Safety control, human factors, 
and other activities that have an impact on the performance, reputation, or security of an organization can be given as examples of operational risks.

Logistics risks in two main groups will be examined collectively; in other words, they will not be examined separately. The experts sequenced the logistics risks are shown above in order of importance. The logistics risks ranking of the experts is represented in Table 1.

Table 1. Experts' Ranking of Logistics Risks.

\begin{tabular}{cccccc}
\hline Logistics Risks & Expert 1 & Expert 2 & Expert 3 & Expert 4 & Expert 5 \\
\hline GLR & 8 & 9 & 9 & 8 & 9 \\
TPR & 2 & 3 & 2 & 2 & 2 \\
NDR & 9 & 8 & 8 & 9 & 7 \\
PCR & 3 & 2 & 4 & 3 & 3 \\
IVR & 1 & 1 & 1 & 1 & 1 \\
INFR & 5 & 4 & 3 & 4 & 5 \\
ORR & 7 & 5 & 5 & 5 & 4 \\
PKR & 4 & 6 & 7 & 7 & 6 \\
OPR & 6 & 7 & 6 & 6 & 8 \\
\hline
\end{tabular}

Beginning with the second logistics risk, each expert uses triangular neutrosophic values (TNV) to each logistics risk for comparison. As an example, the logistics risk comparisons of Expert 1 are given in Table 2.

Table 2. Expert 1's Logistics Risks Comparisons.

\begin{tabular}{ccccc}
\hline Risks & Rankings & Risks & Linguistic Values & TNV \\
\hline GLR & 8 & IVR & - & - \\
TPR & 2 & TPR & WS & $((0.15,0.25,0.10), 0.60,0.20,0.30)$ \\
NDR & 9 & PCR & WS & $((0.15,0.25,0.10), 0.60,0.20,0.30)$ \\
PCR & 3 & PKR & FWS & $((0.40,0.35,0.50), 0.60,0.10,0.20)$ \\
IVR & 1 & INFR & VWS & $((0.10,0.30,0.35), 0.10,0.20,0.15)$ \\
INFR & 5 & OPR & VWS & $((0.10,0.30,0.35), 0.10,0.20,0.15)$ \\
ORR & 7 & ORR & VSS & $((0.90,0.85,0.90), 0.70,0.20,0.20)$ \\
PKR & 4 & GLR & WS & $((0.15,0.25,0.10), 0.60,0.20,0.30)$ \\
OPR & 6 & NDR & ES & $((0.65,0.60,0.70), 0.80,0.10,0.10)$ \\
\hline
\end{tabular}

Each logistics risk's contradiction degree is equally determined as $1 / 8$. As shown in Table 2, a logistics risk comparisons table is created for each expert. TNVs in these tables are combined with Equation (4). In other words, it means that all judgments of all experts are aggregated. These aggregated values are converted into crisp numbers by Equation (5). Aggregated triangular neutrosophic values and crisp values $\left(v_{j}\right)$ are represented in Table 3.

Table 3. Aggregated Triangular Neutrosophic Values and Crisp Values.

\begin{tabular}{ccc}
\hline Risks & Aggregated TNV & $\boldsymbol{v}_{j}$ \\
\hline IVR & - & - \\
TPR & $((0.018,0.300,0.690), 0.028,0.188,0.526)$ & 0.165 \\
PCR & $((0.020,0.288,0.616), 0.064,0.188,0.583)$ & 0.133 \\
INFR & $((0.044,0.432,0.877), 0.057,0.200,0.371)$ & 0.223 \\
ORR & $((0.034,0.354,0.840), 0.046,0.163,0.475)$ & 0.192 \\
PKR & $((0.178,0.594,0.939), 0.209,0.138,0.445)$ & 0.309 \\
OPR & $((0.043,0.354,0.768), 0.149,0.169,0.500)$ & 0.192 \\
NDR & $((0.160,0.547,0.924), 0.236,0.113,0.363)$ & 0.319 \\
GLR & $((0.042,0.341,0.684), 0.195,0.175,0.578)$ & 0.171 \\
\hline
\end{tabular}


The logistics risks' rankings with respect to experts are integrated with the arithmetic mean. Then, Equations (6)-(8) are utilized to identify logistics risks' weights. The conclusions of the Plithogenic SWARA method are indicated in Table 4.

Table 4. The Conclusions of the Plithogenic SWARA.

\begin{tabular}{cccccc}
\hline Risks & Rankings by Arithmetic Mean & $\boldsymbol{v}_{j}$ & $\boldsymbol{y}_{j}$ & $z_{j}$ & $\boldsymbol{w}_{j}$ \\
\hline IVR & 1 & - & 1 & 1 & 0.202 \\
TPR & 2 & 0.165 & 1.165 & 0.858 & 0.173 \\
PCR & 3 & 0.133 & 1.133 & 0.757 & 0.153 \\
INFR & 4 & 0.223 & 1.223 & 0.619 & 0.125 \\
ORR & 5 & 0.192 & 1.192 & 0.519 & 0.105 \\
PKR & 6 & 0.309 & 1.309 & 0.396 & 0.080 \\
OPR & 7 & 0.192 & 1.192 & 0.332 & 0.067 \\
NDR & 8 & 0.319 & 1.319 & 0.252 & 0.051 \\
GLR & 9 & 0.171 & 1.171 & 0.215 & 0.043 \\
\hline
\end{tabular}

Logistic risks are listed with respect to Table 4 as follows; IVR, TPR, PCR, INFR, ORR, PKR, OPR, NDR and GLR. According to the results of the Plithogenic SWARA method, the most important logistics risk was determined as IVR.

\section{Discussion}

The logistics sector has high uncertainty in its operations; therefore, the risk is higher in this sector. Recently, logistics risks have evolved to be more complex, with several issues faced within recent decades such as environmental problems and demand fluctuations. In these conditions, it has become important to analyze risks better for logistics firms to succeed. There are several studies about logistics risks in the literature [12-17]. However, in this study, a new MCDM method, the Plithogenic SWARA method, was introduced to the literature. By means of the Plithogenic SWARA method, individual decisions can be combined without the loss of information in group decision-making problems. In this study, nine logistics risks were evaluated under two main groups. Two main groups were determined as collaboration and non-collaboration-based logistics risks. However, the logistics risks in these two main groups have not been examined separately. The reason for this is to be able to determine which logistics risk is more important in general. According to the analysis results, the most important logistics risk was determined as IVR logistics risk. According to Plithogenic SWARA results, collaboration-based logistics risks are listed as follows: IVR, TPR, PCR, INFR, PKR, and OPR, on the other hand, non-collaborationbased logistics risks are listed as follows: ORR, NDR, and GLR. Since IVR is the most important risk associated with logistics in general, logistics managers should attempt to reduce this risk. ORR is the most important of the non-collaboration-based logistics risks. In general, non-collaboration-based logistics risks were identified as the least important risks. According to a similar study done by Ulutaş et al. [63], the most important logistics risk was determined as transportation-related risks, and inventory-related risks were determined as the third most important logistics risk. This study, unlike the study of Ulutaş et al. [63], examined nine criteria under two main groups. However, when both this study and Ulutaş et al. [63]'s study is examined, it is seen that the first three logistics risks, namely transportation-related risks, purchasing-related risks, and inventory-related risks, do not change. Therefore, logistics managers need to be careful against these three logistics risks.

Although logistic risks were analyzed with a novel method which is Plithogenic SWARA, the number of criteria and decision-makers used in this study is very low. Particularly, the number of non-collaboration-based risks is very low. This is one of the limitations of this study. Govindan and Chaudhuri [64] examines more criteria and considers collaboration compared to this study; however, the mitigation strategies of these risks are not mentioned. It can be suggested for the future studies that the mitigation strategies for these risks can be developed. 


\section{Conclusions}

Because of the uncertainty in logistics operations, such as robbery, weather conditions, and environmental variables, the logistics business has traditionally operated in a high-risk environment. However, since the corporate environment has changed in recent years with globalization, environmental problems, and demand shifts, these risks have become considerably more complicated. To thrive as a logistics firm, it is important to evaluate and assess the risks associated with logistics.

In this study, the Plithogenic SWARA method is developed to assess and prioritize the logistics risks. The neutrosophic data were taken from five experts working in the logistics sector. The experts first identified nine logistics risks under two main groups, which are collaboration-based and non-collaboration-based logistics risks for assessment. By using the first steps of the Plithogenic SWARA method, neutrosophic data obtained from experts were aggregated, and then aggregated neutrosophic data were converted into crisp data. By using the final steps of Plithogenic SWARA, the crisp importance values (weights) of logistic risks are determined by means of these crisp data. According to the results of the Plithogenic SWARA method, the logistics risks are listed as follows; IVR, TPR, PCR, INFR, ORR, PKR, OPR, NDR and GLR. While the most important of these logistics risks was IVR, the least important logistics risk was determined as GLR. This study contributes to the literature as it develops a new Plithogenic MCDM method. In addition, with this study, the most important logistics risk was determined, and it was tried to help the managers working in the logistics sector. The Plithogenic SWARA method can be used without losing information in group decision making problems compared to the traditional SWARA method. The Plithogenic SWARA method can be used to solve other MCDM problems (performance evaluation, machine selection and supplier selection etc.) in future studies. Also, for further studies, this methodology can be discussed with other methodologies for consistency and comparing. In this study, for the first time the risks have been divided by two parts as collaboration-based and non-collaboration-based logistics risks. So, it will be expected as an important discussion for further studies in the literature. In future studies this risk management may be utilized for humanitarian logistics assessment and maturity levels for logistics.

Author Contributions: Conceptualization, A.U., A.T., I.M.-K. and E.D.; methodology, A.U. and E.D.; validation, A.U.; formal analysis, A.U. and I.M.-K.; resources, A.U.; data curation, A.U.; writingoriginal draft preparation, A.U., A.T. and E.D.; writing—review and editing, I.M.-K. All authors have read and agreed to the published version of the manuscript.

Funding: This research received no external funding.

Institutional Review Board Statement: Not applicable.

Informed Consent Statement: Not applicable.

Data Availability Statement: The data of this study is available from the authors upon request.

Conflicts of Interest: The authors declare no conflict of interest.

\section{References}

1. Giannakis, M.; Papadopoulos, T. Supply chain sustainability: A risk management approach. Int. J. Prod. Econ. 2016, 171, 455-470. [CrossRef]

2. ISO. Risk Management-Guidelines. 2018. Available online: https://www.iso.org/obp/ui/\#iso:std:iso:31000:ed-2:v1:en (accessed on 12 August 2021).

3. GIZ. The Vulnerability Sourcebook. Concept and Guidelines for Standardised Vulnerability Assessments. 2017. Available online: https:/ / www.adaptationcommunity.net/download/va/vulnerability-guides-manuals-reports/vuln_source_2017_EN. pdf (accessed on 12 August 2021).

4. Deloach, J.W. Enterprise-Wide Risk Management: Strategies for Linking Risk and Opportunity; Financial Times Prentice Hall: London, UK, 2000.

5. Norrman, A.; Jansson, U. Ericsson's proactive supply chain risk management approach after a serious sub-supplier accident. Int. J. Phys. Distrib. Logist. Manag. 2004, 34, 434-456. [CrossRef] 
6. Abdel-Basset, M.; Gunasekaran, M.; Mohamed, M.; Chilamkurti, N. A framework for risk assessment, management and evaluation: Economic tool for quantifying risks in supply chain. Future Gener. Comput. Syst. 2019, 90, 489-502. [CrossRef]

7. Radanliev, P.; De Roure, D.C.; Nicolescu, R.; Huth, M.; Montalvo, R.M.; Cannady, S.; Burnap, P. Future developments in cyber risk assessment for the internet of things. Comput. Ind. 2018, 102, 14-22. [CrossRef]

8. $\quad$ Birkel, H.S.; Veile, J.W.; Müller, J.M.; Hartmann, E.; Voigt, K.I. Development of a risk framework for Industry 4.0 in the context of sustainability for established manufacturers. Sustainability 2019, 11, 384. [CrossRef]

9. Lyu, H.M.; Sun, W.J.; Shen, S.L.; Zhou, A.N. Risk assessment using a new consulting process in fuzzy AHP. J. Constr. Eng. Manag. 2020, 146, 04019112. [CrossRef]

10. Van Wassenhove, L.N. Humanitarian aid logistics: Supply chain management in high gear. J. Oper. Res. Soc. 2006, 57, 475-489. [CrossRef]

11. Hapeman, K. The effects of politics on natural disasters: Lessons learned from Bangladesh. In Case Specific Briefing Paper Humanitarian Aid in Complex Emergencies; University of Denver: Denver, CO, USA, 2012; Available online: https:/ /www.du.edu/ korbel/crric/media/documents/katie_hapeman1.pdf (accessed on 12 August 2021).

12. Oklander, M.A.; Yashkin, D.S. Methodological approaches to logistic risks assessment. Econ. Time Realities 2014, 3, 37-42.

13. Baharmand, H.; Comes, T.; Lauras, M. Managing in-country transportation risks in humanitarian supply chains by logistics service providers: Insights from the 2015 Nepal earthquake. Int. J. Disaster Risk Reduct. 2017, 24, 549-559. [CrossRef]

14. Chand, M.; Raj, T.; Shankar, R.; Agarwal, A. Select the best supply chain by risk analysis for Indian industries environment using MCDM approaches. Benchmarking Int. J. 2017, 24, 1400-1413. [CrossRef]

15. Kubasova, T.; Tkach, V.; Tsvigun, I. Priorities of the logistics risks management in the resource support of construction projects. In Proceedings of the 2018 International Scientific Conference Investment, Construction, Real Estate: New Technologies and Special-Purpose Development Priorities (ICRE 2018), Barcelona, Spain, 2-4 October 2018; pp. 1-8.

16. Khan, S.; Khan, M.I.; Haleem, A.; Jami, A.R. Prioritising the risks in Halal food supply chain: An MCDM approach. J. Islamic Mark. 2019. [CrossRef]

17. Panjehfouladgaran, H.; Lim, S.F.W. Reverse logistics risk management: Identification, clustering and risk mitigation strategies. Manag. Decis. 2020, 58, 1449-1474. [CrossRef]

18. Cavinato, J.L. Supply chain logistics risks: From the back room to the board room. Int. J. Phys. Distrib. Logist. Manag. 2004, 34, 383-387. [CrossRef]

19. Jereb, B.; Ivanuša, T.; Rosi, B. Systemic Thinking and Requisite Holism in Mastering Logistics Risks: The Model for Identifying Risks in Organisations and Supply Chain. Amfiteatru Econ. J. 2013, 15, 56-73.

20. Pokrovskaya, O.; Reshetko, N.; Kirpicheva, M.; Lipatov, A.; Mustafin, D. The study of logistics risks in optimizing the company's transportation process. In IOP Conference Series: Materials Science and Engineering; IOP Publishing: Dolny, Poland, 2019; pp. 1-8.

21. Prakash, S.; Soni, G.; Rathore, A.P. Multi-echelon closed-loop supply chain network design and configuration under supply risks and logistics risks. Int. J. Logist. Syst. Manag. 2017, 28, 1-23. [CrossRef]

22. Cagliano, A.C.; Grimaldi, S.; Rafele, C. A structured approach to analyse logistics risks in the blood transfusion process. J. Healthc. Risk Manag. 2021, 41, 18-30. [CrossRef] [PubMed]

23. Wang, C.; Regan, A.C. Reducing Risks in Logistics Outsourcing; University of California Transportation Center, UC Berkeley: Berkeley, CA, USA, 2003; Available online: https:/ / escholarship.org/uc/item/47v6f9fx (accessed on 1 September 2021).

24. Wang, M.; Asian, S.; Wood, L.C.; Wang, B. Logistics innovation capability and its impacts on the supply chain risks in the Industry 4.0 era. Mod. Supply Chain Res. Appl. 2020, 2, 83-98. [CrossRef]

25. Ofluoglu, A.; Birdogan, B.; Ar, İ.M. Determining of Disaster Logistics Risks Based on Literature Review. J. Manag. Mark. Logist. 2019, 6, 1-9. [CrossRef]

26. Kodym, O.; Kubáč, L.; Kavka, L. Risks associated with Logistics 4.0 and their minimization using Blockchain. Open Eng. 2020, 10, 74-85. [CrossRef]

27. Selviaridis, K.; Spring, M.; Profillidis, V.; Botzoris, G. Benefits, risks, selection criteria and success factors for third-party logistics services. Marit. Econ. Logist. 2008, 10, 380-392. [CrossRef]

28. Li-jun, Z. Research on analysis and control of enterprise logistics outsourcing risks. Energy Procedia 2012, 17, 1268-1273. [CrossRef]

29. Salanța, I.; Popa, M. Managing the Risks of Failure in Outsourcing Logistics: Evidence from Romania. Manag. Chall. Contemp. Soc. 2015, 8, 89-94.

30. Liu, J.; Zhou, H.; Sun, H. A three-dimensional risk management model of port logistics for hazardous goods. Marit. Policy Manag. 2019, 46, 715-734. [CrossRef]

31. Babazadeh, R.; Razmi, J. A robust stochastic programming approach for agile and responsive logistics under operational and disruption risks. Int. J. Logist. Syst. Manag. 2012, 13, 458-482. [CrossRef]

32. Moslemi, A.; Hilmola, O.P.; Vilko, J. Risks in emerging markets: Logistics services in the Mediterranean region. Marit. Bus. Rev. 2016, 1, 253-272. [CrossRef]

33. Varzandeh, J.; Farahbod, K.; Zhu, J.J. Global logistics and supply chain risk management. J. Bus. Behav. Sci. 2016, $28,124$.

34. Wu, P.J.; Chaipiyaphan, P. Diagnosis of delivery vulnerability in a logistics system for logistics risk management. Int. J. Logist. Manag. 2019, 31, 43-58. [CrossRef]

35. Pfohl, H.C.; Gallus, P.; Thomas, D. Interpretive structural modeling of supply chain risks. Int. J. Phys. Distrib. Logist. Manag. 2011, 41, 839-859. [CrossRef] 
36. Yongsheng, L.; Li, J. Design of early warning indicator system for enterprise logistics risks based on balanced scorecard. In Proceedings of the 2010 International Conference on Intelligent Computation Technology and Automation, Changsha, China, 11-12 May 2010; pp. 27-31.

37. Jia, X.; Zhang, D. Prediction of maritime logistics service risks applying soft set based association rule: An early warning model. Reliab. Eng. Syst. Saf. 2021, 207, 107339. [CrossRef]

38. Liu, P.; Wang, S. Evolutionary game analysis of cold chain logistics outsourcing of fresh food enterprises with operating risks. IEEE Access 2020, 8, 127094-127103. [CrossRef]

39. Chang, C.H.; Xu, J.; Song, D.P. Risk analysis for container shipping: From a logistics perspective. Int. J. Logist. Manag. 2015, 26, 147-171. [CrossRef]

40. Roșca, E.; Raicu, S.; Roșca, M.; Rusca, F.V. Risks and Reliability Assessment in Maritime Port Logistics. Adv. Mater. Res. 2014, 1036, 963-968. [CrossRef]

41. Chen, T.; Wu, S.; Yang, J.; Cong, G. Risk propagation model and its simulation of emergency logistics network based on material reliability. Int. J. Environ. Res. Public Health 2019, 16, 4677. [CrossRef]

42. Yan, Y.; Suo, B. Risks Analysis of Logistics Financial Business Based on Evidential Bayesian Network. Math. Probl. Eng. 2013, 2013, 785218. [CrossRef]

43. Lai, K.H.; Vejvar, M.; Lun, V.Y. Risk in port logistics: Risk classification and mitigation framework. Int. J. Shipp. Transp. Logist. 2020, 12, 576-596. [CrossRef]

44. Gao, H. Research on logistics risks of fresh e-commerce products from the perspective of supply chain management. In Proceedings of the 2nd International Conference on Urban Engineering and Management Science (ICUEMS), Sanya, China, 29-31 January 2021; pp. 40-43.

45. Lee, S.W. Proposal to mitigate arctic shipping and logistics risks utilizing fourth industrial technology. In Proceedings of the 2017 North Pacific Arctic Conference, Hawaii, HI, USA, 9-11 August 2017; pp. 250-260.

46. Lakehal, A.; Tachi, F. Probabilistic assessment of road risks for improving logistics processes. In Proceedings of the 12th International Conference Quality Production Improvement (QPI 2018), Zaborze, Poland, 18-20 June 2018.

47. Wang, M. Impacts of supply chain uncertainty and risk on the logistics performance. Asia Pac. J. Mark. Logist. 2018, 30, 689-704. [CrossRef]

48. Behl, A.; Dutta, P. Humanitarian supply chain management: A thematic literature review and future directions of research. Ann. Oper. Res. 2019, 283, 1001-1044. [CrossRef]

49. Sahin, A.; Ertem, M.A.; Emür, E. Using containers as storage facilities in humanitarian logistics. J. Humanit. Logist. Supply Chain. Manag. 2014, 4, 286-307. [CrossRef]

50. Baporikar, N.; Shangheta, L.B. Challenges Facing Humanitarian Logistics in a Nonprofit Organization. Int. J. Appl. Logist. 2018, 8, 35-56. [CrossRef]

51. Beresford, A.; Pettit, S. Humanitarian aid supply chain management. In Contemporary Operations and Logistics; Wells, P., Ed.; Palgrave Macmillan: Cham, Switzerland, 2019.

52. Oloruntoba, R.; Hossain, G.F.; Wagner, B. Theory in humanitarian operations research. Ann. Oper. Res. 2019, 283, 543-560. [CrossRef]

53. Cozzolino, A. Humanitarian logistics and supply chain management. In Humanitarian Logistics; Springer: Berlin/Heidelberg, Germany, 2012.

54. Oloruntoba, R.; Gray, R. Humanitarian aid: An agile supply chain? Supply Chain. Manag. 2006, 11, 115-120. [CrossRef]

55. Kosacka-Olejnik, M. Logistics maturity model in the service industry: State of art and research implications. LogForum 2020, 16, 261-269. [CrossRef]

56. Oleśków-Szłapka, J.; Stachowiak, A. The framework of logistics 4.0 maturity model. In Intelligent Systems in Production Engineering and Maintenance; Burduk, A., Chlebus, E., Nowakowski, T., Tubis, A., Eds.; Springer: Cham, Switzerland, 2018; Volume 835, pp. 771-781.

57. Facchini, F.; Oleśków-Szłapka, J.; Ranieri, L.; Urbinati, A. A maturity model for logistics 4.0: An empirical analysis and a roadmap for future research. Sustainability 2020, 12, 86. [CrossRef]

58. Duran, F.; Zafeirakopoulos, İ.B. Environmental risk assessment of e-waste in reverse logistics systems using MCDM methods. In Proceedings of the International Symposium for Production Research, Vienna, Austria, 13-15 September 2017; pp. 590-603.

59. Mzougui, I.; Carpitella, S.; Certa, A.; El Felsoufi, Z.; Izquierdo, J. Assessing supply chain risks in the automotive industry through a modified MCDM-based FMECA. Processes 2020, 8, 579. [CrossRef]

60. Teniwut, W.A. Challenges in reducing seaweed supply chain risks arising within and outside remote islands in Indonesia: An integrated MCDM approach. In Sustainability Modeling in Engineering: A Multi-Criteria Perspective; World Scientific Publishing Company: Singapore, 2019; pp. 271-291.

61. Vishwakarma, V.; Prakash, C.; Barua, M.K. A fuzzy-based multi criteria decision making approach for supply chain risk assessment in Indian pharmaceutical industry. Int. J. Logist. Syst. Manag. 2016, 25, 245-265. [CrossRef]

62. Senthil, S.; Murugananthan, K.; Ramesh, A. Analysis and prioritisation of risks in a reverse logistics network using hybrid multi-criteria decision making methods. J. Clean. Prod. 2018, 179, 716-730. [CrossRef] 
63. Ulutaş, A.; Topal, A.; Karabasevic, D.; Stanujkic, D.; Popovic, G.; Smarandache, F. Prioritization of logistics risks with plithogenic PIPRECIA method. In Proceedings of the International Conference on Intelligent and Fuzzy Systems, Istanbul, Turkey, 24-26 August 2021; pp. 663-670.

64. Govindan, K.; Chaudhuri, A. Interrelationships of risks faced by third party logistics service providers: A DEMATEL based approach. Transp. Res. Part E Logist. Transp. Rev. 2016, 90, 177-195. [CrossRef]

65. Karakurt, N.F.; Cem, E.; Çebi, S. A new risk analysis approach for operational risks in logistic sector based on fuzzy best worst method. In International Conference on Intelligent and Fuzzy Systems; Springer: Cham, Switzerland, 2021; pp. 696-702.

66. Yousefia, S.; Rezaeea, M.J.; Moradi, A. Causal effect analysis of logistics processes risks in manufacturing industries using sequential multi-stage fuzzy cognitive map: A case study. Int. J. Comput. Integr. Manuf. 2020, 33, 1055-1075. [CrossRef]

67. Thakkar, J.J. An integrated DEMATEL-ANP (DANP) MCDM approach for quantifying the supply chain risk: A case of Indian petroleum supply chain. In Multi-Criteria Decision Making; Springer: Singapore, 2021; pp. 349-365.

68. Gaudenzi, B.; Borghesi, A. Managing risks in the supply chain using the AHP method. Int. J. Logist. Manag. 2006, 17, 114-136. [CrossRef]

69. Shanker, S.; Sharma, H.; Barve, A. Assessment of risks associated with third-party logistics in restaurant supply chain. Benchmarking Int. J. 2021, 28, 2432-2464. [CrossRef]

70. Cheng, Q.; Yu, L. Operational mechanism and evaluation system for emergency logistics risks. Int. J. Intell. Syst. Appl. 2010, 2, 25-32. [CrossRef]

71. Kwak, D.W.; Rodrigues, V.S.; Mason, R.; Pettit, S.; Beresford, A. Risk interaction identification in international supply chain logistics: Developing a holistic model. Int. J. Oper. Prod. Manag. 2018, 38, 372-389. [CrossRef]

72. Sandberg, E. Logistics collaboration in supply chains: Practice vs. theory. Int. J. Logist. Manag. 2007, 18, 274-293. [CrossRef]

73. Barratt, M. Understanding the meaning of collaboration in the supply chain. Supply Chain. Manag. Int. J. 2004, 9, 30-42. [CrossRef]

74. Chapman, R.L.; Soosay, C.; Kandampully, J. Innovation in logistics services and the new business mode: A conceptual framework. Manag. Serv. Qual. Int. J. 2002, 12, 358-371. [CrossRef]

75. Stank, T.P.; Keller, S.B.; Daugherty, P.J. Supply chain collaboration and logistical service performance. J. Bus. Logist. 2001, 22, 29-48. [CrossRef]

76. Silva, S.C.; Bradley, F.; Sousa, C.M.P. Empirical test of the trust-performance link in an international alliances context. Int. Bus. Rev. 2012, 21, 293-306. [CrossRef]

77. Chow, P.T.; Cheung, S.O.; Chan, K.Y. Trust-building in construction contracting: Mechanism and expectation. Int. J. Proj. Manag. 2012, 30, 927-937. [CrossRef]

78. Mohr, J.; Nevin, J. Communication strategies in marketing channels: A theoretical perspective. J. Mark. 1990, 54, 36-51. [CrossRef]

79. Zolfani, S.H.; Saparauskas, J. New application of SWARA method in prioritizing sustainability assessment indicators of energy system. Eng. Econ. 2013, 24, 408-414. [CrossRef]

80. Abdel-Basset, M.; Manogaran, G.; Mohamed, M.; Chilamkurti, N. Three-way decisions based on neutrosophic sets and AHP-QFD framework for supplier selection problem. Future Gener. Comput. Syst. 2018, 89, 19-30. [CrossRef]

81. Abdel-Basset, M.; Mohamed, R.; Zaied, A.E.N.H.; Gamal, A.; Smarandache, F. Solving the supply chain problem using the best-worst method based on a novel Plithogenic model. In Optimization Theory Based on Neutrosophic and Plithogenic Sets; Academic Press: Massachusetts, MA, USA, 2020; pp. 1-19.

82. Smarandache, F. Plithogenic Set, an Extension of Crisp, Fuzzy, Intuitionistic Fuzzy, and Neutrosophic Sets-Revisited. Neutrosophic Sets Syst. 2018, 21, 153-166.

83. Smarandache, F. Plithogeny, Plithogenic Set, Logic, Probability, and Statistics; Pons Publishing House: Brussels, Belgium, 2017.

84. Keršuliene, V.; Zavadskas, E.K.; Turskis, Z. Selection of rational dispute resolution method by applying new step-wise weight assessment ratio analysis (SWARA). J. Bus. Econ. Manag. 2010, 11, 243-258. [CrossRef] 